The regulations in the 1979 Penal Code on bribery and other forms of corruption were too simple. Only four types of crime were defined: corruption, bribe-taking, bribery and brokerage bribery, with the first grouped under property encroachment and the other three under malfeasance or dereliction of duty. The 1988 Supplementary Regulations on Punishment for Bribery and Other Corruption Crimes, promulgated by the NPC Standing Committee, had made major revisions and additions to the relevant regulations in the 1979 Penal Code and represented the first step in efforts to establish a fairly comprehensive system for defining bribery and other acts of corruption, including bribetaking, bribery, embezzlement of public funds, unclear origin of huge assets and concealment of deposits abroad.

To meet the need to combat corruption and strengthen efforts to crack down on bribery and other forms of corruption, the highest legislative body originally planned to formulate a special normative anti-corruption and bribery document (the Anti-Corruption and Bribery Law) to be drafted by the Supreme People's Procuratorate. Proceeding from the principle of devising a unified, relatively complete, penal code, the current revision embraced the compilation of the Additional Regulations on Punishing Corruption and Bribery Crimes (adopted by the NPC Standing Committee in 1988) and the anti-corruption and bribery law (now being drafted by the Supreme People's Procuratorate) in a chapter in the specific provisions of the new penal code. New charges, such as illegal distribution of stateowned assets and illegal distribution of fines and confiscation were added and the anti-corruption and bribery criminal punishment norms made more effective and descriptive. The legislative body has incorporated the Draft Regulations of the People's Republic of China on the Punishment of Servicemen for Anti-Duty Crimes, which was submitted by the Central Military Commission to the Standing Committee of the Eighth NPC for deliberations, into the new penal code as the final chapter of the Specific Principles, after making certain revisions and additions. Such a measure has guaranteed the completeness of the new penal code system as well as the authenticity of its role and functions; it is also conducive to putting the army onto the modern rule-of-law track.

Thirdly, in compliance with the practical need for the criminal law to protect the healthy development of the market economy and to safeguard state and social stability under the social market economy, the new penal code has greatly strengthened the categories of charges. From the point of view of the crime categories in the chapters and articles covered, the new Specific Principles section has created a special chapter on crimes endangering national defence, besides adding a new chapter incorporating servicemen's offences and creating a separate chapter dealing with corruption and bribery. At the same time, it has substantiated and divided into eight sections the third chapter, which dealt with crimes disrupting the socialist market economy; and substantiated and divided into nine sections the sixth chapter, which dealt with crimes impeding social administration. The new penal code has added over 150 new charges besides retaining most of those in the 1979 Penal Code as well as others added later, bringing the number of offences in China's criminal law to a total of 413. Such crimes as organising, leading or joining terrorist organisations, hijacking ships or vehicles, are all new charges. The addition of new offences, relating to new categories of crime, has strengthened and modernised China's new penal code, which will help to bring about social development and prosperity.

Part Two of this article will be published in the next issue of Amicus Curiae. (1)

\section{Dr Ye Feng}

Senior member of the Supreme People's Procuratorate; Director of the Institute of Procuratorial Theory; Secretary General of the Society of Public Prosecutors of China

\title{
The Netherlands
}

\section{Contingency fees entering the Dutch legal system by Leny E de Groot-van Leeuwen}

I $\mathrm{n}$ the Netherlands the wind blows from the west most of the time. Perhaps that is why the Dutch adopt so many legal features and procedures from the US, such as plea bargaining, alternative dispute resolution and contingency fees for attorneys. The discussion on contingency fees (or 'no cure, no pay' as the Dutch say) flared up recently, sparked by Attorney Mr G Engelgeer, who sued the Dutch Bar Association (Nederlandse Orde van Advocaten ('NOVA') for not allowing them.

According to this attorney, the restrictions the DBA imposes on competition among its members violate the national and European law. Mr Engelgeer grounds his complaints in a recently published set of 'points for consideration' from the Dutch Competition Authority (Nederlandse mededigingsautoriteit, 'NMa') in which it is stated that the current prohibition on contingency fees should be banned.

The complaints against the NOVA have fallen on fertile soil This soil has been prepared by the European Union, which views the Netherlands as a paradise for cartels. The EU has forced the NMa to adopt a strictly pro-competition stance, with the objective of pushing the Dutch style of conducting business in a more open-market direction (without sacrificing the Dutch culture of consensus, i.e. the much-praised 'polder model', to which the cartel-style of business is closely connected).

The NMa's view is only one stone in an avalanche of decisions pertaining to all other sectors of business. The relevance of the contingency fees case lies at a deeper level, in that, as far as the 
NMa is concerned, the attorney's activities are viewed as simply one type of business among others.

The traditional concept of the profession of attorney in the Netherlands is far removed from that of competitive market behaviour. Traditionally, attorneys were not supposed to visit their clients nor to advertise their services; they were expected to be independent of their clients and to exercise restraint if their client's interests conflicted with those of third parties or the public good. The attorney's remuneration was therefore considered as an 'honorary fee'. Obviously the present discussion has moved a long way from this original position.

\section{EXISTING BILLING REGULATIONS}

Contingency fees are more or less common practice in the US but not yet in Europe. In Germany, for instance, fixed fees according to the type of activity are common practice. The billing system in the Netherlands is still based on a fee per hour. Traditionally, the Dutch Bar used to set a fixed fee for all attorneys but this practice was dropped in 1997 under pressure from the pro-competition lobby.

Contingency fees are still prohibited, however. Rule 25 of the Code of Conduct of the Bar contains the following statements:

'(1) The attorney is not free to agree with a client to be remunerated only if the case has a certain result', and

(2) 'The attorney shall not agree with a client that the remuneration will consist of a certain proportion of the value of the result of the attorney's effort, except in categories of cases for which the Bar Association has advised a tariff.'

In current practice, this exception to the pars quota litis prohibition consists only of a debt-collecting commission, which can be agreed upon between the debt-collecting attorney and his client.

\section{ARGUMENTS IN FAVOUR}

In the current discussions all arguments voiced in favour of contingency fees are based on the market-oriented paradigm. The NMa is against the restrictions of art. 25 because they reduce competition and hence violate art. 6 of the Competition Act (Mededingingswet). This article prohibits:

\footnotetext{
. . all agreements between companies, decisions of company associations and co-ordinated actions of companies aimed at or resulting in precluded, reduced or distorted competition.'
}

Besides this rather general argument, it is sometimes claimed that contingency fees will result in improved promotion of the client's interest because the attorney has a direct stake in winning the case and, contrary to the billing system, the attorney has an interest in dealing with the case as quichly as possible. Furthermore, the client does not need to spend time checking whether billed hours are actually worked.

The most important argument in favour, however, is that contingency fees result in improved access to justice, due to the fact that the financial consequences of litigation are shifted from the client to the attorney in exchange for a part of the spoils. This also shifts the decision to file a case to the one who is most competent, so that the number of hopeless cases will be reduced. Finally, it will also be easier for the client to compare the offers of different attorneys.

\section{ARGUMENTS AGAINST}

Most arguments put forward against contingency fees are based on the image of the bar as a profession. One claim, for instance, is that the objective of art. 25 of the Code of Conduct is to protect the client and hence has nothing to do with a price agreement. The prohibition of pars quota litis guarantees the independence of the attorney and with that a proper execution of professional duties. The relationship of trust between attorney and client would suffer if the system of remuneration forced the attorney to look after his or her own financial interests during the development of a case. The relationship of trust between attorney and judge would deteriorate likewise.

Another consequence of contingency fees, as pointed out by the opponents, is that attorneys would direct their energies towards cases where big money can be found, such as injury cases. Consequently, energy spent on cases where justice, rather than money, is the issue would be reduced.

Many opponents of contingency fees refer to the attorney's duty always to aim for a peaceful settlement rather than continue in conflict mode to the very end (art. 3 of the code).

Opponents of contingency fees often refer to 'American conditions' as a spectre of the future if contingency fees were allowed. (This imagery includes ambulance chasing and outrageous claiming behaviour, but excludes, of course, lawyers billing more than 24 hours per day or dragging on with lost lawsuits only in order to raise the bill, as can happen under a non-contingency-fee system.)

A further argument against contingency fees is that they would reinforce the tendency to hunt other professionals, such as those in the medical system, with malpractice and similar suits, thereby greatly raising the cost of these systems (through insurance premiums, for example). The effect of the contingency fees would then be that the collective good of an accessible medical system would be undermined by a constant drain of money to the pockets of insurance companies, malpractice lawyers and 'lucky' individual clients.

\section{THE FUTURE}

The defenders of the traditional profession seem to be fighting a lost battle. In the longer run it would appear that, in modern societies, traditional ways of practice can survive only under a centralised 'pooling' system of remuneration, in which payments depend on clients and services only through a system operated above the level of the individual. Examples of the latter are the national health service and the Church; within these, at least in the Netherlands, doctors and the clergy survive as 'undiluted' professions.

For professions outside that type of system - and the Bar in the Netherlands is one of these - the tensions between traditional values and the logic of the market appear too deep to allow for simple solution by mixing some of each. The current debate on contingency fees, therefore, rather than ending in shallow compromise, should be seen as an opportunity to develop a new type of profession within the market.

\section{Leny E de Groot-van Leeuwen}

University of Utrecht and University of Nijmegen 